\title{
JUDICIARIES IN CORRUPT SOCIETIES
}

\author{
MIKAEL PRIKS
}

\section{CESIFO WORKING PAPER NO. 2008 \\ CATEgORY 1: PUblic FinANCE \\ JUNE 2007}
An electronic version of the paper may be downloaded
- from the SSRN website:
- from the RePEc website: www.SSRN.com Www.RePEc.org
- from the CESifo website: www.CESifo-group.de




\title{
JUDICIARIES IN CORRUPT SOCIETIES
}

\begin{abstract}
Recent empirical work shows that judicial dependence can explain high levels of corruption. This paper examines how the dependence of judiciaries influences corruption at different levels of the government in a model where the central government, low-level officials, and the judiciary are corrupt. In the model, the central government sells offices to low-level officials and demands ex-post payments enforced by the judiciary. Because an independent judiciary can rule against the central authority and accept bribes from stealing low-level officials, it reduces corruption at the higher level of government but promotes corruption at the lower level. Therefore, even if highly corrupt, an independent judiciary may reduce total corruption. We provide empirical evidence which is in line with this result.
\end{abstract}

JEL Code: H11, K40.

Keywords: judiciaries, corruption.

Mikael Priks
Center for Economic Studies at the
University of Munich
Schackstr. 4
80539 Munich
Germany
mikael.priks@Imu.de

May 23, 2007

This paper was written in part while I was visiting Harvard University and in part at Stockholm University. I wish to thank Philippe Aghion, Alberto Alesina, Fredrik Andersson, Stefano Della Vigna, Rafael Di Tella, Nicola Gennaioli, Edward Glaeser, Bengt Holmström, Sten Nyberg, Torsten Persson, Per Pettersson-Lidbom, Ilia Rainer, Jesper Roine, Andrei Shleifer, Stergios Skaperdas, David Strömberg, Jakob Svensson, Jenny Säve-Söderbergh, Jean Tirole, Francesco Trebbi, Thierry Verdier, HansWijkander and seminar participants at Harvard University, Stockholm University, the Stockholm School of Economics, the Institute for Industrial Research in Stockholm, the Public Choice Annual Conference in San Diego, the University of Munich, NUI at Maynooth and the CEU Workshop in Budapest on Comparative Institutional Economics for their helpful comments. 


\section{Introduction}

Corruption is a widespread phenomenon in both developing and developed countries. Not surprisingly, economists have devoted substantial attention to the study of the determinants, as well as the effects of corruption (see for instance Rose-Ackerman 1978, Klitgaard 1988 and Shleifer and Vishny 1993).

A question which has recently attracted attention in the empirical literature is how the degree to which the judiciary is dependent of the government affects corruption (Ades and Di Tella 1997 and La Porta et al. 2004). These studies show that dependent judiciaries typically increase corruption, but little has been done in the theoretical literature on the topic. ${ }^{1}$

In this paper, we offer a theory showing that the structure of the judiciary will determine the level of corruption at different levels of the government administration. We find that an independent judiciary, even though highly corrupt, may reduce corruption.

Previous literature on corruption and institutional design has typically focused on corruption at the lower level of government and taken the higher level to be benevolent (Shleifer and Vishny 1993 and Banerjee 1996). However, available empirical evidence suggests that both high-level politicians and judiciaries commonly abuse power in their own interest. To get an idea of the extent of corruption within judiciaries, we examine a recent World Bank survey in which firms in 71 countries answer to the question "In resolving business disputes, do you believe your country's court system to be Honest/Uncorrupt". ${ }^{2}$ On a scale where 1 denotes "always" and 6 denotes "never" the answering score is, on average, 3.65, which implies that the judiciaries, in fact, are closer to being "dishonest/corrupt" than "honest/uncorrupted" ${ }^{3}$

\footnotetext{
${ }^{1}$ Ades and di Tella (1997) show this in cross-country regressions using different indexes of corruption. La Porta et al. (2004) find that independent judiciaries reduce the number of steps that a start-up firm has to comply with in order to start operating legaly. In addition, La Porta et al. (1999) and Djankov et al. (2002) show that compared to common law countries, civil law countries (which tend to have more dependent judiciaries (La Porta el al. 2004)) have worse regulation and more bureaucratic delays.

${ }^{2}$ The World Bank's World Business Environment Survey 1997 "Measuring Conditions for Business Operation and Growth".

${ }^{3}$ We first calculate the average of the firms' answers in each country and then the overall average of this.
} 
In order to study how different types of judiciaries affect corruption it is therefore important to understand the interaction of different levels of government with respect to corruption. To do this we introduce a model where officials sell government goods, such as permits or import licenses, and where all agents, i.e., a central authority (e.g. a president, minister, etc.), a judiciary and officials, are assumed to act solely in their own interests. The central authority can either extract rents up front or ex post. Up-front collection is costly due to ex-ante auction inefficiencies and ex-post collection is costly because officials may steal. ${ }^{4}$ The judiciary's role is to find out if theft has occurred and to implement the sentence.

In line with North and Weingast (1989), Glaeser and Shleifer (2002) and La Porta et al. (2004) we define an independent judiciary as one that can rule against the central authority. In particular, it can avoid reporting theft to the central authority in exchange for taking bribes from stealing officials. ${ }^{5}$ Theft is therefore common in this system, which lead the central authority to extract rents through up-front collection, by way of allowing officials to earn large rents, rather than collecting fees ex post. A dependent judiciary, in contrast, can be fully controlled by the central authority, which uses its coercive power to penalize officials harshly. To exploit the fact that theft is scarce the central authority adopts ex-post collection of rents, which reduces corruption on the part of the officials along with increasing corruption on part of the central authority.

We argue that the structure of the judiciary may also affect the central authority's choice of competition among officials. The degree of competition is determined by the trade-off between the amounts of rents the central authority can extract up-front when selling the office and ex post when collecting variable fees. If the judiciary is dependent, then competition among officials may be used by the central authority to

\footnotetext{
${ }^{4}$ An illustrative example of our model showing how corruption at different levels occur interdependently is given by Wade (1982) who studies the strategic corrupt usage of a canal irrigation system in India in the early 1980s. Under this system, farmers consistently had to bribe lower level officials in order to direct water to their fields. Well aware of the surplus this created, the minister in charge of irrigation used a two-part tariff system to extract rents. First, ex ante, potential officials had to make up-front payments in order to become an official and then they paid additional fees during tenure.

${ }^{5}$ Russia of today is an example of this mechanism where influence by regional governments over courts is the central problem of the rule of law (Glaeser and Shleifer 2002).
} 
expand ex-post revenues. Again, because a dependent judiciary reduces the probability of theft it increases the central authority's profits whereas it squeezes officials' rents. ${ }^{6}$

In sum, an independent judiciary generates large rents for officials through the low penalty they pay for theft whereas the central authority benefits from a dependent judiciary, which uses a harsher penalty. With an intermediate penalty, however, neither officials nor the central authority can extract high rents at the expense of the other so total corruption is therefore scarce. In other words, even if highly corrupt, an independent judiciary has the benefit that it curtails the monopoly power of the central authority at the cost of creating opportunities for officials to seek rents.

In terms of the expected price level of the government good, a dependent judiciary typically increases it because ex-post fees are high and theft rare. Consumers therefore indirectly benefit from an independent judiciary. ${ }^{7}$

We furthermore examine the implications of our model against empirical evidence. We use unique data containing a variable capturing the degree of the dependency of the judiciaries, which serve well as an approximation of the assumptions of our model. The proxy we create is based on the US Department of State's (and the Heritage Foundation's "Index of Freedom 2001") evaluation of the degree to which the judiciary is subject to influence from the executive authority. ${ }^{8}$ The results show that corruption is positively associated with the dependency of the judiciary, which lends some support to the earlier empirical literature.

The paper is related to several strands of the literature. The model takes its starting point in Shleifer and Vishny (1993), but differs in that the officials are exploited by the

\footnotetext{
${ }^{6}$ Similar to our findings, Rose-Ackerman (1978) and Shleifer and Vishny (1993) argue that competition among officials reduces corruption at the lower level of government. This is also supported by Gurgur and Shah (2000) in a cross-country analysis. However, we show that it can actually be selected by a corrupt central authority to increase its revenues and that this choice is a function of the structure of the judiciary.

${ }^{7}$ However, if competition among officials is selected when the judiciary is dependent but not when it is independent, then a dependent judiciary generates a lower price.

${ }^{8}$ This differs from La Porta et al. (1999) and Djankov et al. (2002) who use legal origin as a proxy for the dependency of the judiciary, La Porta et al. (2004) who use tenure of judges and whether judicial decisions are a source of law as a proxy, and Ades and Di Tella (1997) who use an index from Business International.
} 
central authority and that the judiciary is modeled. ${ }^{9}$ Becker and Stiegler (1974), and later Carmichael (1985), have emphasized a mechanism of rent extraction similar to ours in which some of the officials' rents could accrue to the government if they were required to post bonds up front. In our model, however, the up-front payment is not a bond but a sunk cost.

Similar to our model, Glaeser and Shleifer (2002) argue that independent judiciaries are vulnerable to taking bribes. While they focus on explaining why independent and dependent judiciaries have come about (in 12th century England and France) we study their affect on the distributions of rents. Huther and Shah (2000) and Stephenson (2001) finally argue that uncorrupted independent judiciaries reduce corruption. We show in a micro-founded model that this may be true even if they are corrupt.

The paper proceeds as follows. The model is introduced in Section 2 where we also analyze differences between an independent and a dependent judiciary. Competition among officials is considered in Section 2.4. In Section 2.5 we considered the welfare aspects of the model and in section 2.6 we solve the model assuming a benevolent central authority to compare with earlier literature. Section 3 considers some empirical evidence. Section 4 concludes.

\section{A Micro-founded Model of Corruption}

We consider the provision of a single homogeneous government-produced good, say a permit. Consumers have a linear inverse demand for the permits, $p(q)=a-b q$, where $a$ and $b$ are constants and $q$ is the number of permits allocated by one official. We initially consider the case where permits are provided by a single government official who can constrain the quantity of permits. The central authority (CA) uses officials to extract rents from consumers. The CA sells the offices for up-front payments, and demands a fee, $\theta \geq 0$, per permit sold, which is paid ex post. ${ }^{10}$ The CA is assumed to

\footnotetext{
${ }^{9}$ In Shleifer and Vishny (1993), the fee officials pay is a real exogenous cost to the government. In our model, the fee is determined by the central authority in order to extract rents.

${ }^{10}$ Several studies show that valuable offices are sold first (Huntington 1968, Wade 1982, 1984, Riordan 1995 and Coolidge and Rose-Ackerman 1997) after which the central authority often expects
} 
use an auction in which case it collects non-refundable bribes, $\mathbf{x}$, from several potential officials but only one official gets the office.

As in Shleifer and Vishny (1993), officials can cover up the sale of permits but may then get caught by the judiciary, i.e., the authority who can intervene and penalize officials. ${ }^{11}$ The penalty, $t$, is independent of the amount of theft. This is motivated by the empirical fact that the structure of law against corruption tends to be relatively insensitive to the scale of corruption (see Banerjee 1995, 1996). The CA cannot take more from a stealing official than the official's ex-ante wealth, $\bar{t} .{ }^{12}$ The decision whether to monitor officials or not for a fixed cost $c>0$ and the size of the penalty are determined by the $\mathrm{CA}$ in the case of a dependent judiciary and by the judiciary in the case of an independent judiciary. The game is solved by backward induction starting at stage three when the official sells the permits.

\subsection{Stage three: the market for permits}

The profit of the official is given by

$$
\pi=(a-b q) q-\theta q
$$

where, $\theta$, is the fee per permit determined by the CA and $a \geqslant \theta$. The profit maximizing number of permits is

$$
q^{*}(\theta)=\frac{a-\theta}{2 b}
$$

Hence, the price, or bribe, consumers have to pay to acquire a permit is given by

$$
p^{*}(\theta)=\frac{a+\theta}{2} .
$$

more payments in terms of variable fees (Wade 1982, 1984, Shleifer and Vishny 1993 and Djankov et al. 2002).

${ }^{11}$ In theory, the CA would know how much is stolen even without the judiciary and hence would do well without it. However, we find it reasonable to assume that it cannot keep track of payments and thus needs the judiciary as a bookkeeper. It may also be the case that the judiciary is needed to verify theft. In addition, official may steal and then promptly leave the position. To prevent this, the CA needs to monitor the official.

${ }^{12}$ Similarly, Polinsky and Shavell (2001) model an upper limit on the penalty representing the lawbreaker's maximum wealth. 
Thus the profit of the official is equal to

$$
\pi^{N T}(\theta)=\frac{(a-\theta)^{2}}{4 b}
$$

where the superscript $N T$ denotes a no theft case. In the case of theft the official pays no fee, i.e., $\theta=0$. Consequently, the profit when issuing permits without paying the fee, is given by ${ }^{13}$

$$
\pi^{T}=\frac{a^{2}}{4 b} .
$$

However, while theft increases the profits it also exposes the official to the risk of getting caught and penalized.

\subsection{Stage two: The game between the judiciary and officials}

At stage two, the theft, monitoring and penalty decisions are made. Consider first a dependent judiciary where the $\mathrm{CA}$ takes the monitoring decision and decides the penalty. ${ }^{14}$

\subsubsection{A dependent judiciary}

The penalty if the judiciary is dependent is $t_{D}=\bar{t}$ since the central authority is constrained only by limited liability on the part of the official. ${ }^{15}$ The payoffs determining

\footnotetext{
${ }^{13}$ The results do not change qualitatively if we instead assume that the official steals some fraction, $\gamma$, of $\pi^{T}$, such that $\gamma \pi^{T}>\pi^{N T}$.

${ }^{14}$ Note that the central authority and the judiciary coincide in this case.

${ }^{15}$ Our results do not change qualitatively if we instead allow the penalty to be a function of the uncovered amount of corruption, and let the judiciary take the stealing official's ex-post wealth, $t_{D}=\bar{t}+\frac{a^{2}}{4 b}$.
} 
the monitoring and theft decisions are shown in Figure 1.

\begin{tabular}{c|l|c|l|}
\multicolumn{4}{c}{ Central Authority } \\
\cline { 2 - 4 } Official & \multicolumn{1}{c|}{ Monitor } & Not Monitor \\
\cline { 2 - 4 } & Theft & $\pi^{T}-t_{D}, t_{D}-c$ & $\pi^{T}, 0$ \\
\cline { 2 - 4 } & No Theft & $\pi^{N T}, \theta q^{*}(\theta)-c$ & $\pi^{N T}, \theta q^{*}(\theta)$ \\
\hline
\end{tabular}

Figure 1. The Game between the Central Authority and the Official.

We assume that $\pi^{T}-t_{D}<\pi^{N T}$ and that $t_{D}>c$ so there are no pure strategy equilibria of the game. We later show that these are not restrictive assumptions.

We solve for the mixed strategy equilibrium that would make the CA indifferent between monitoring and not monitoring, and the official indifferent between stealing and not stealing. The mixed strategy equilibrium probability of theft, $\mu$, becomes

$$
\mu=\frac{c}{t_{D}}
$$

Note that the higher penalty, the lower is the probability of theft. ${ }^{16}$ The mixed strategy equilibrium probability of monitoring, $\lambda$, is equal to

$$
\lambda=\theta \frac{2 a-\theta}{4 b t_{D}}
$$

The CA's expected profits from the fees are in equilibrium equal to

$$
\Pi^{F}=\mu \lambda\left(t_{D}-c\right)+(1-\mu) \lambda\left(\theta q^{*}(\theta)-c\right)+(1-\lambda)(1-\mu) \theta q^{*}(\theta)=(1-\mu) q^{*}(\theta) \theta
$$

An interesting feature of this model is that the CA's revenues from the penalty and the cost of monitoring the official cancel in equilibrium. This is because in the mixedstrategy equilibrium, the CA's expected profit has to be the same from monitoring and

\footnotetext{
${ }^{16}$ Goel \& Rich (1989) and Goel and Nelson (1998) using US state data show that the probability that officials take bribes decreases as the penalties for corruption increases.
} 
not monitoring. The expected profit for the official is equal to

$$
\pi^{*}(\theta)=\frac{(a-\theta)^{2}}{4 b}
$$

which is identical to the case of no theft. The reason is that the official in equilibrium is made indifferent between stealing and not stealing.

\subsubsection{An independent judiciary}

Consider instead an independent judiciary who takes the monitoring decision and determines the size of the penalty, $t_{I}$. Because it does not have to report theft to the central authority, there are bargaining possibilities both between the CA and the judiciary and between the judiciary and the official. The surplus can be shared in different ways depending on bargaining power and preferences, etc. Our main result is not sensitive to the particular assumptions we make. Assume, for simplicity, that the official has full bargaining power with the judiciary. ${ }^{17}$ The CA will announce a division of the surplus, such that the judiciary receives a share, $s$, of the maximum the central authority can take, i.e., st. However, the CA may not (or may not be able) to commit to its announcement. ${ }^{18}$ To handle this, we let the CA be able to commit to this decision with a probability, $0 \leq \phi \leq 1$, and ask what effect the commitment problem has on the division of the surplus, and hence on the penalty. ${ }^{19}$

Lemma 1 In equilibrium, $t_{I}^{*}<t_{D}=\bar{t} \forall t$ when $\phi<1$.

Proof. A stealing official, which has been caught will always have incentives to bribe the judiciary not to report to the CA. The bribe will be equal to what the judiciary expects to receive from the CA: $s \phi \bar{t}$ or lower depending upon bargaining

\footnotetext{
${ }^{17}$ The mechanism works as long as the judiciary does not have full bargaining power with the official.

${ }^{18}$ Full commitment is a strong assumption since the CA has incentives to take as much as possible from the judiciary ex post. Olson (2000) finds that commitment is difficult since dictators often have a short time horizon. Moreover, Bardhan (1997 p. 1325) writes: "This ability to credibly commit is a feature of "strong" states that very few developing countries have."

${ }^{19}$ To focus on how the structure of judiciaries affect corruption we do not model the underlying reasons for why the probability to commit is low or high.
} 
power between the judiciary and the stealing official. Thus, knowing that theft will never be reported, the CA's only objective is to minimize theft, which it does when $s=1$. Hence, the official will pay the judge at most $\phi \bar{t}$ in order not to report the theft to the CA, which will be his penalty, $t_{I}^{*}$.

Thus, whenever the CA cannot commit with a probability equal to one it ends up in a bad scenario with much theft and with no revenues from the judiciary. ${ }^{20}$ However, we believe that this typically is one of the features of an independent judiciary.

The game between the official and the judiciary is shown in Figure 2. We assume for simplicity that the judiciary earns no profit when it does not monitor the officials.

\section{The Judiciary}

\begin{tabular}{|l|l|l|l|}
\cline { 2 - 4 } \multicolumn{1}{c|}{ Official } & \multicolumn{1}{|c|}{ Monitor } & Not Monitor \\
\cline { 2 - 4 } & Theft & $\pi^{T}-t_{I}^{*}, t_{I}^{*}-c$ & $\pi^{T}, 0$ \\
\cline { 2 - 4 } No Theft & $\pi^{N T},-c$ & $\pi^{N T}, 0$ \\
\hline
\end{tabular}

Figure 2. The Game between the Judiciary and the Official.

This game is similar to Figure 1 with the difference that the penalty is $t_{I}^{*}$ instead of $t_{D}$ and that the judiciary does not obtain revenues when the official does not steal. The probability of theft and monitoring are identical to when the judiciary is dependent apart from the fact that the penalty is different. Importantly, because $t_{I}^{*}<t_{D}$ the probability of theft is higher in the case of independent judiciary. This implies that the CA's revenues are lower in the case of independent judiciary compared to when the judiciary is dependent. Nevertheless, from the perspective of stage 2 the officials profits is the same, $\pi^{N T}=\frac{(a-\theta)^{2}}{4 b}$. The reason is that in the mixed strategy equilibrium, the official's profit from theft will be equal to the the profit from no theft. Similarly, the judiciary's profit from monitoring will be equal to the profit in case of no monitoring. In other words, the judiciary will, in equilibrium, not earn any revenues.

\footnotetext{
${ }^{20}$ We could assume that collusion between the official and the judiciary could be detected by the CA with some probability. Mookerjee and Png (1995) and Polinsky and Shavell (2001) in related models include such governmental monitoring. Such an extension would not change the qualitative results of the model.
} 


\subsection{Stage one: the choice of officials and fees}

At stage one, the CA sells the office and decides the level of the fee. We assume that $n$ identical potential officials compete for the office and that the CA uses the following mechanism where the probability to become an official, $\psi_{i}$, for a potential official $i$ is given by

$$
\psi_{i}=\frac{x_{i}}{\sum_{j=1}^{n} x_{j}}
$$

The more (non-refundable) bribes, given by $x_{i}$, potential official $i$ pays the CA up-front relative to the bribes of all $n$ potential officials, the higher is the probability to become an official. ${ }^{21}$ A potential official $i$ maximizes

$$
\pi_{i}=\frac{x_{i}}{\sum_{j=1}^{n} x_{j}} \pi^{*}(\theta)-x_{i}
$$

with respect to the bribe where we know from before that $\pi^{*}(\theta)$ is the value of holding office. Note that the profit in the objective function is identical to the no-theft because although actually implementing a mixed strategy, they expect ex ante the no-theft payoff level. In equilibrium, the optimal bribe for any one official is equal to

$$
x^{*}=\frac{n-1}{n^{2}} \pi^{*}(\theta) .
$$

Since the bribes are non-refundable, the CA's income from bribes at the first stage of the game is equal to

$$
n x^{*}=\frac{n-1}{n} \pi^{*}(\theta) .
$$

Note that as $n \rightarrow \infty, n x^{*} \rightarrow \pi^{*}(\theta)$.

\footnotetext{
${ }^{21}$ This probability contest success function, originally used by Tullock (1980) for the analysis of rent-seeking contests and subsequently widely used in that literature, does not necessarily maximize the CA's revenues. However, it may reflect reality fairly well when it is illegal to sell offices. In this case, the CA cannot openly announce any price mechanism, which would maximize revenues, and therefore this may be a natural second best solution. In addition, bribes cannot be rebated to those failing to receive the office, because then it would be clear that he was selling favors. Baye et al. (1993) argue that this is exactly what happens in many lobbying campaigns. They write, "It is natural, therefore, for a political institution to arise such that lobbyist "ante up" before the prize is awarded, and these up-front payments are not refundable to those failing to win the prize" (Baye et al. 1993, p. 289).
} 
An alternative setup is that the CA's revenue is determined in a bargaining process between the CA and potential officials. Since it is reasonable to assume that the CA's bargaining power increases in the number of potential officials, qualitatively our results would remain in such a setting. Another example is if officials borrow in order to buy the office and if they have private information about their interest rate, then a first price sealed bid auction yields an identical result. In fact, any mechanism with the properties that the CA cannot extract the full value of the office, which is increasing in the number of potential officials, would generate the basic insights of the model..$^{22}$

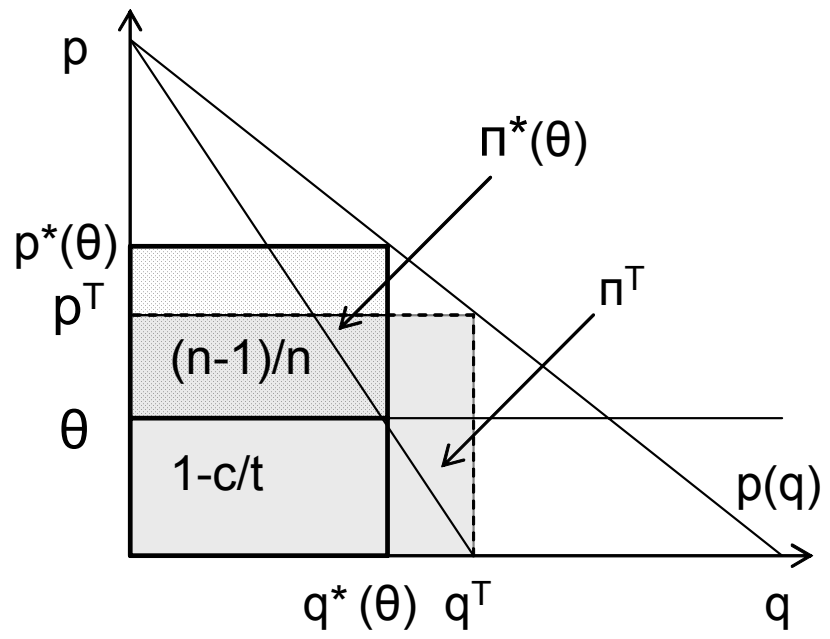

Figure 3. An Illustration of the Model.

In Figure 3 the model is illustrated. The demand for permits and the parameters $n$, $c$ and $t$, determines how much the CA can extract from officials. The CA's problem is to find the fee, $\theta$, that maximizes its profit, $\Pi$, which consists of the up-front payments $\frac{n-1}{n} \pi^{*}(\theta)$ and the incomes from fees $\left(1-\frac{c}{t}\right) \theta q^{*}(\theta)$. Increasing the fee, $\theta$, will increase the CA's revenues from fees. However, the cost is that officials' expected profit, $\pi^{*}(\theta)$, is reduced, which reduces the CA's incomes when selling the office.

We assume that the CA can commit to its ex-ante announcement of the fee. Thus,

\footnotetext{
${ }^{22}$ Efficient menu auctions (see e.g. Bernheim and Whinston 1986) would not, but they are only possible if the potential officials can make negative contributions (Boylan 2000).
} 
the CA solves the following problem

$$
\max _{\theta} \Pi^{M}=\frac{n-1}{n} \pi^{*}(\theta)+\left(1-\frac{c}{t}\right) \theta q^{*}(\theta)
$$

where the superscript $M$ denotes monopoly. Note that $t=\bar{t}$ in the case of a dependent judiciary and $t=t_{I}^{*}$ in the case of an independent judiciary. The first-order condition is equal to

$$
\frac{a\left(1-\frac{n-1}{n}-\frac{c}{t}\right)+\theta\left(\frac{n-1}{n}-2\left(1-\frac{c}{t}\right)\right)}{2 b}=0
$$

and the unique optimal fee is given by

$$
\theta^{*}=\frac{a}{2}\left(1-\frac{\frac{n-1}{n}}{2\left(1-\frac{c}{t}\right)-\frac{n-1}{n}}\right)
$$

The fee is positive as long as $t>n c$. In the case of an independent judiciary, the fee is positive if $\phi \bar{t}>n c$. For example, if $\phi$ is very low, then it follows that the optimal fee may well be equal to zero. ${ }^{23}$ The CA's profit, $\Pi^{M}$, is equal to

$$
\Pi^{M}=\frac{\left(1-\frac{c}{t}\right)^{2}}{2\left(1-\frac{c}{t}\right)-\frac{n-1}{n}} \pi^{T} .
$$

From equation (3) it is evident that the price of permits in case of theft is equal to $\frac{a}{2}$ while it is higher in the case of no theft. The expected price level is given by

$$
E\left(p^{*}\right)=\frac{a}{2}\left(\frac{c}{t}+\left(1-\frac{c}{t}\right)\left(1-\frac{\frac{n-1}{n}-1+\frac{c}{t}}{2\left(1-\frac{c}{t}\right)-\frac{n-1}{n}}\right)\right) .
$$

We now turn to defining the levels of corruption. First, we define petty corruption as the profit of holding office less the payment that is done in order to get the office

$$
P^{C}=\frac{\left(a-\theta^{*}\right)^{2}}{4 b n}=\frac{\left(1-\frac{c}{t}\right)^{2}}{n\left(\frac{n-1}{n}-2\left(1-\frac{c}{t}\right)\right)^{2}} \pi^{T} .
$$

\footnotetext{
${ }^{23}$ We will assume a positive fee, i.e., that $t>n c$, which subsumes the earlier assumption $t>c$.
} 
Second, we define grand corruption as the CA's profit

$$
G^{C}=\Pi^{M}
$$

Third, and finally, total corruption is the sum of these two.

Consider how the dependency of the judiciary affects the level of corruption.

Proposition 2 As compared to an independent judiciary, a dependent judiciary will be associated with a higher optimal fee, a higher price level for the government good, more grand corruption and less petty. It leads to less (more) total corruption if

$$
t<(>) \frac{3+n+\sqrt{n^{2}+6 n-7}}{4} c n \text {. }
$$

\section{Proof. See Appendix A.}

The intuition is that the CA's incomes (grand corruption) from fees are higher in a dependent system due to the low probability of theft. Because of this, the CA increases the fee, which, in turn, reduces petty corruption. ${ }^{24}$ Total corruption tends to be reduced when the judiciary is dependent because fewer permits are issued. However, the harsher the penalty the larger is the CA's income, and for sufficiently large penalties this effect dominates such that total corruption increases if the judiciary is dependent. Interestingly, consumers indirectly benefit from an independent judiciary. The reason is that the $\mathrm{CA}$ is constrained, which leads it to select relatively low variable fees.

A related topic is the optimal choice of the structure of the judiciary (see Glaeser and Shleifer 2002). In our model, we note that a corrupt CA would always select a dependent judiciary to reduce theft.

\footnotetext{
${ }^{24} \mathrm{An}$ alternative definition of petty corruption is that it equals the extent to which officials commit theft, $\mu=\frac{c}{t}$. Since a dependent judiciary implies that the penalty is higher compared to an independent judiciary, the results on petty corruption would be similar under this assumption.
} 


\subsection{Competition among officials}

Let us extend the analysis to encompass the possibility that several officials sell permits in competition. From the CA's point of view, the benefit of competition is increased sale of government goods. However, competition also reduces the officials' willingness to pay for the office along with decreasing the probability that the $\mathrm{CA}$ will receive the payments ex post. We ask two questions. First, what are the effects of competition on the price level and on the levels of corruption? Second, what will be the optimal number of officials chosen by the CA?

Assume there are $N>1$ identical officials selling the permit, that officials compete in prices and the goods are perfect substitutes. ${ }^{25}$ The price, $p=a-b \sum_{i=1}^{N} q_{i}$, is in equilibrium when nobody steals equal to the fee, $\theta$, so the quantity provided by one official is in this case equal to

$$
q^{*}(\theta)=\frac{a-\theta}{N b}
$$

The profit without theft, or if more than one official steals, is equal to zero. The profit for official $i$ if only he steals is $(\theta-\varepsilon) \frac{a-\theta}{b}$ where $\varepsilon \rightarrow 0$. If somebody else steals, then the profit of official $i$ is equal to zero. The game at stage two for official $i$ is shown in Figure 4 where $\mu_{j}$ denotes the probability of theft by another official $j$. When stealing, the probability that nobody else steals is equal to $\left(1-\mu_{j}\right)^{N-1}$. We assume that the penalty, $t$, is independent of the number of thieves and that the officials are monitored independently of each other.

\section{The Judiciary}

\begin{tabular}{|c|c|c|c|}
\hline \multirow{3}{*}{ Off. i } & & Monitor & Not Monitor \\
\hline & Theft & $\left(1-\mu_{j}\right)^{N-1} \frac{\theta(a-\theta)}{b}-t, t-c$ & $\left(1-\mu_{j}\right)^{N-1} \frac{\theta(a-\theta)}{b}, 0$ \\
\hline & No Theft & $0,-c$ & 0,0 \\
\hline
\end{tabular}

Figure 4. The Game between the Judiciary and Officials in Competition.

\footnotetext{
${ }^{25}$ Assuming that the products are differentiated (imperfect substitutes) gives results in similar direction.
} 
We assume that $t>\left(1-\mu_{j}\right)^{N-1} \frac{\theta(a-\theta)}{b}$ and $t>c$. Hence, the mixed strategy equilibrium probability of theft is equal to $\mu=\frac{c}{t}$ and the mixed strategy equilibrium probability of monitoring is equal to $\lambda=\frac{\left(1-\mu_{j}\right)^{N-1} \frac{\theta(a-\theta)}{b}}{t} \cdot{ }^{26}$ Note that the expected value of the game for an official is equal to zero as this is what he earns if he does not steal. The CA's problem is therefore to maximize

$$
\max _{\theta, N} \Pi^{C}=\left(1-\frac{c}{t}\right)^{N} N \theta q^{*}(\theta) \quad \forall N>1
$$

where the superscript $C$ denotes competition. The optimal fee is equal to

$$
\theta^{*}=\frac{a}{2} \forall N>1
$$

and the optimal number of officials is given by

$$
N^{*}=2 \forall N>1
$$

Note that $\theta^{*}$ and $N^{*}$ are independent of the judicial system when $N>1$. The CA's profit (grand corruption) is equal to

$$
\Pi^{C}=\left(1-\frac{c}{t}\right)^{2} \pi^{T}
$$

We use the same notation as before so $\pi^{T}=\frac{a^{2}}{4 b}$ denotes the monopoly value of theft. The officials' expected profit of the game is equal to zero. The expected price level is given by $\frac{a}{2}$ as long as not both steals, i.e.,

$$
E(p)=\frac{a}{2}\left(1-\left(\frac{c}{t}\right)^{2}\right)
$$

We now pose the question: under what conditions would the CA select competition among officials?

\footnotetext{
${ }^{26}$ We here assume that the judiciary is independent. As in the monopoly case, in equilibrium, the only difference to the case of a dependent judiciary is that the penalty is lower in the case of an independent judiciary.
} 
Proposition 3 If $t<2 n c$, then the CA chooses a monopoly. If $t>2 n c$, then two officials will be chosen.

Proof. Competition is chosen if: $\Pi^{C}=\left(1-\frac{c}{t}\right)^{2} \pi^{T}>\frac{\left(1-\frac{c}{t}\right)^{2}}{2\left(1-\frac{c}{t}\right)-\frac{n-1}{n}} \pi^{T}=\Pi^{M}$. This simplifies to the condition $t>2 n c$.

When there is no theft (or if $t=\infty$ ) and when a monopoly can be sold for its full value (or if $n=\infty$ ), then the $\mathrm{CA}$ is indifferent between the two market forms since both are first best solutions. But when the penalty is high and the income from up-front payments low, competition tends to be preferred. The reason is that fees, which the CA fully relies on in competition, will often be collected and that the upfront payments, which a monopoly partly relies on, will be equal to zero. More than two officials is never preferred because all it does is increasing the CA's probability of earning no profit at all.

This is an interesting result since the kind of competition that Shleifer and Vishny (1993) argue should be imposed may well be a corrupt central authority's choice. However, when the CA cannot penalize stealing officials harshly, he tends to grant monopolies instead. An example of this, which fits neatly into our model, is that of feudal Europe where the federal governments were so weak that they could not penalize officials in provinces (Shleifer \& Vishny 1993). As our model predicts the feudal European kings consistently granted monopolies for rent extraction (see for example Swart 1980 and North 1981).

In the following we analyze the effects of competition, first on the price level, and then on different levels of corruption.

Proposition 4 The fee is higher, and the price lower, in competition compared to the monopoly case. In competition, the price level is higher in case of a dependent judiciary compared to an independent judiciary.

Proof. See Appendix A.

We argue that competition has two effects on the price level. First, because officials undercut each other's prices, it reduces the price level as argued by Shleifer \& Vishny 
(1993). Second, since the fee is the only source of income for the CA it will be set high. In fact, the $\mathrm{CA}$ acts as a monopolist with a marginal cost equal to zero, that is, he sets the fee equal to $\frac{a}{2}$. This is also the price level when not both officials steal, which happens with probability $1-\left(\frac{c}{t}\right)^{2}$. In all other cases, the price is equal to zero. Since the probability of theft is not zero, the price level is always lower in competition than in the monopoly case, where it is at least equal to $\frac{a}{2}$. As for a dependent judiciary within competition, it leads to less theft and therefore to a higher expected price level, just as in the monopoly case. The effect is, however, not as strong in the monopoly case since the fee is not affected by the penalty.

Proposition 5 When $t>(2+n+\sqrt{n(n+4)})$ cn, total corruption is higher in competition among officials than when one official is selected. Competition eradicates petty corruption. Within competition, a dependent judiciary leads to more grand corruption than an independent judiciary does.

Proof. See Appendix A.

A harsher penalty leads to more grand corruption within competition because the only effect it has is to reduce the probability of theft. Similar to the Rose-Ackerman's (1978) and Shleifer and Vishny's (1993) theoretical analyzes we find that competition reduces petty corruption and the price level. However, we contrast their results with the fact that competition may lead to more grand corruption than a monopoly would. ${ }^{27}$

Note that three cases can arise when we study how a dependent judiciary affects corruption. First, the penalty may be low enough, both in the case of an independent and a dependent judiciary such that a monopoly is selected in both cases. Second, the difference in the penalty may be such that a dependent judiciary leads to a different institutional structure compared to the case of an independent judiciary. In the independent case, monopoly is selected, whereas in the case of a dependent judiciary,

\footnotetext{
${ }^{27}$ Proposition 3 shows that, for the monopoly case, grand corruption might be higher in the case of dependent judiciary compared to independent judiciary. When the number of officials is endogenous, this is true in the case of competition, but no longer in the monopoly case. The reason is that competition among two officials is selected in the penalty-parameter range when this was possible for the monopoly case.
} 
competition is selected. Third, the penalty may be sufficiently high so that the CA will in both cases select competition. For large enough penalties, total corruption is larger in competition among officials than in the monopoly case.

We now show an example where $a=b=c=1$ and $n=2$. Figure 5 illustrates how the dependency of the judiciary affects the price level. At $t=4$, the CA switches from a monopoly to competition among officials.

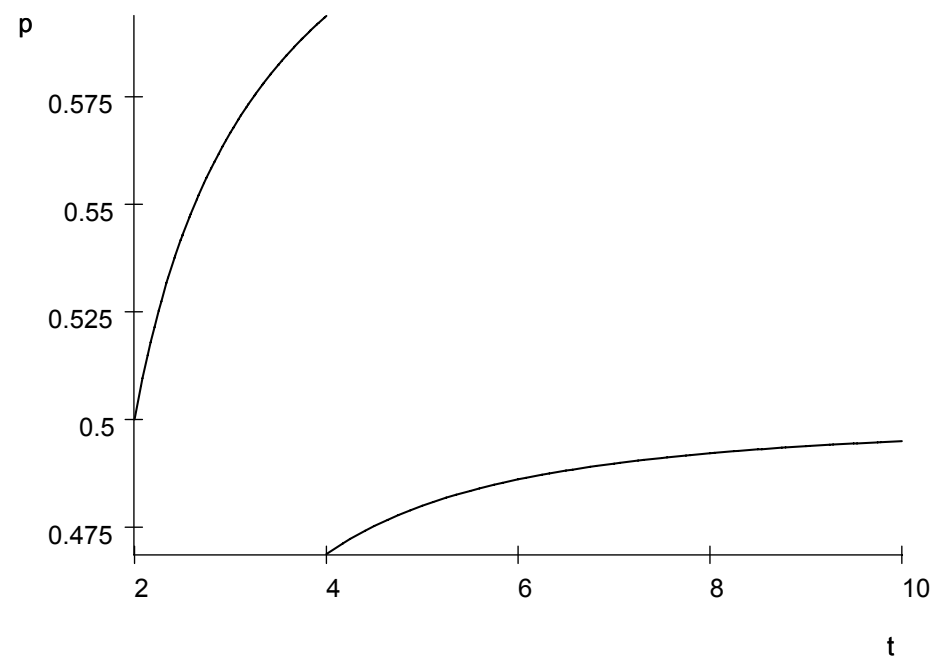

Figure 5. The Dependency of the Judiciary and the Price Level.

Figure 6 illustrates how the dependency of the judiciary affects corruption. The thick grey line shows total corruption, the thin line grand corruption and the medium thick line petty corruption. 


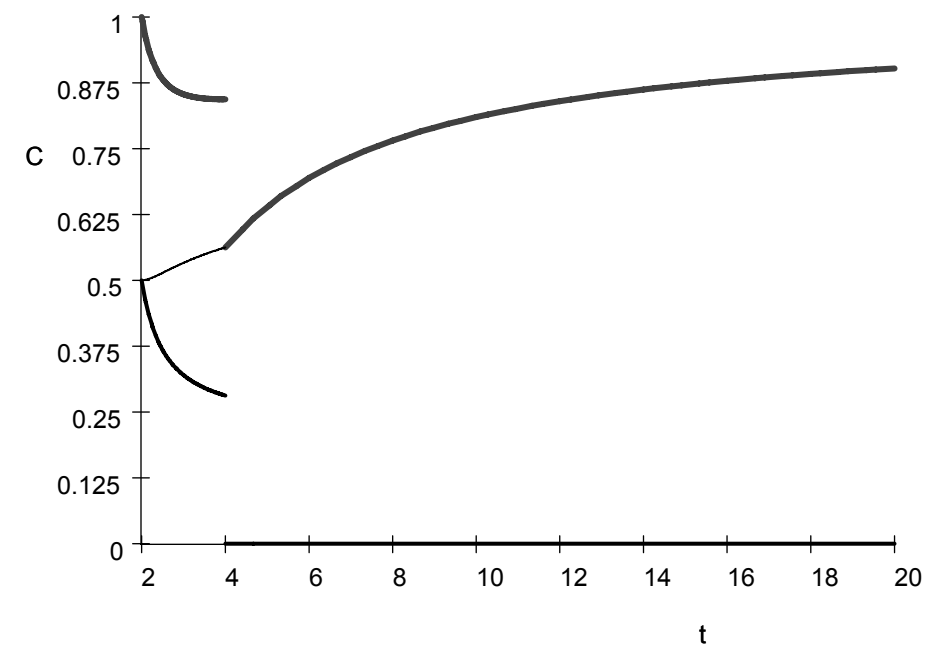

Figure 6. The Dependency of the Judiciary and Corruption.

Note that when $t \geq 4$ petty corruption is equal to zero and that grand corruption therefore coincides with total corruption. It can be shown that for the threshold value $t=2 n c$ (when the $\mathrm{CA}$ is indifferent between a monopoly and competition), total corruption is always higher in the monopoly case. When switching from a monopoly to competition (i.e. when $t=2 n c$ ), petty corruption is eradicated and total corruption reduced. We can also observe that if the penalty is intermediate, then the level of total corruption is low. An interpretation of this is that when the power between officials and the $\mathrm{CA}$ is divided, total corruption is low. In a nutshell, this kind of competition reduces the profits of the $\mathrm{CA}$ and officials, which in this model is the same as reducing corruption.

\subsection{Welfare analysis}

We define social welfare as the sum of consumer surplus, which is the value of the fees, the rents from office, less monitoring costs. The penalty, $t$, constitutes a transfer from stealing officials to the judiciary not affecting social welfare. Thus, in the monopoly 
case, social welfare, $W^{M}$, is equal to

$$
W^{M}=\left(1-\frac{c}{t}\right)\left(\frac{(a-p(\theta)) q(\theta)}{2}+\pi(\theta)+\theta q(\theta)\right)+\frac{c}{t}\left(\frac{\pi^{T}}{2}+\pi^{T}\right)-\theta \frac{2 a-\theta}{4 b t} c .
$$

The first term on the right hand side is consumer surplus plus the value of the office plus the value of the fees in the case when the official does not steal. The second term is consumer surplus plus the value of the office in the case of theft and the last term is the cost of monitoring. In the competition case, social welfare is equal to

$$
W^{C}=\left(1-\left(\frac{c}{t}\right)^{2}\right) \frac{\left(a-\frac{a}{2}\right) q^{C}(\theta)}{2}+\left(\frac{c}{t}\right)^{2} 2 \pi^{T}+\left(1-\frac{c}{t}\right)^{2} \pi^{T}-2 \frac{\left(1-\frac{c}{t}\right) \pi^{T}}{t} c .
$$

The first term is consumer surplus if not both officials steal. The second term is consumer surplus if both steal, the third term the value of fees if nobody steals and the last term the cost of monitoring two officials.

Let us now examine how social welfare is affected by whether the judiciary is dependent or independent of the CA. We note that it may depend on the degree of competition among officials. The model gives the following results.

Proposition 6 In competition, a dependent judiciary is associated with more welfare than an independent judiciary. In the monopoly case, the effect is ambiguous.

\section{Proof. See Appendix A.}

First, consider the case of competition between two officials. Recall that if both officials steal, then the price is driven down to zero. This eliminates the dead weight loss. A dependent judiciary has two effects on welfare. It reduces the probability of theft, which reduces welfare because it increases the dead weight loss, and it reduces the amount of monitoring, which increases welfare. In this model, the second effect dominates. Hence, in the case of competition, a dependent judiciary increases social welfare. 


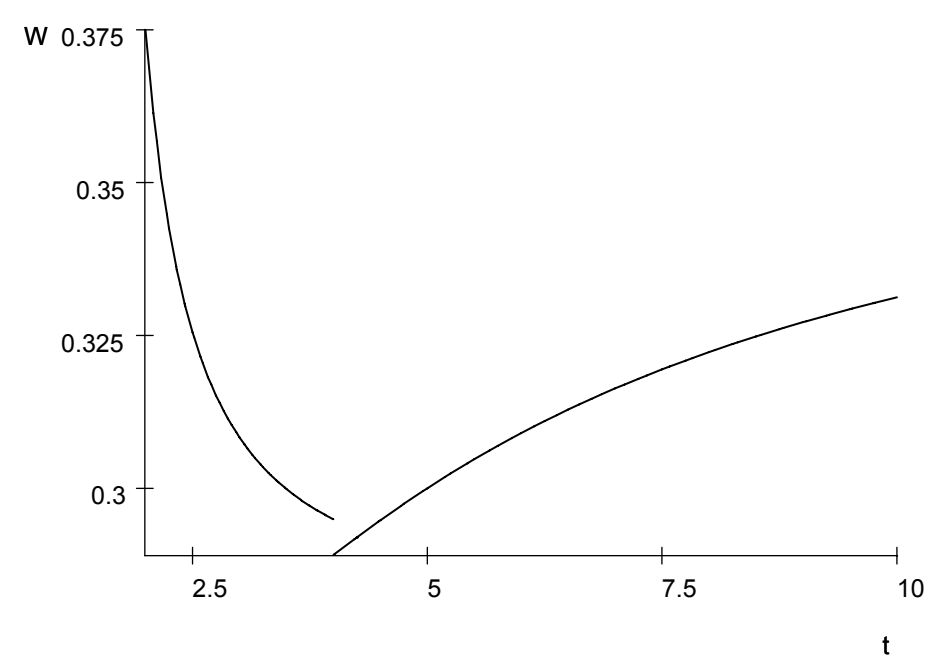

Figure 7. The Dependency of the Judiciary and Welfare.

Second, in the monopoly case a dependent judiciary implies a high fee. This increases the value of fees but reduces consumer surplus and the value of office. Because the effect on the probability of monitoring is ambiguous the total effect is ambiguous as well. In the above example, when $a=b=c=1$ and $n=2$, a dependent judiciary reduces welfare in the monopoly case as shown in Figure \%. Even though we cannot in general determine whether a monopoly generates more social welfare than competition or not, it is possible to show that in the threshold (when $t=2 n c$ ), welfare is always higher in the monopoly case.

Comparing with Figure 6, we note that the penalty affects welfare in a similar way as it affects total corruption. This idea that corruption enables consumers to overcome regulation is not new (see e.g. Leff 1964 and Huntington 1968). Leff (1964 p. 11), for example, states "...if the government has erred in its decision, the course made possible by corruption may well be the better one". However, our analysis is partial and there is a vast literature dealing with reasons for why corruption is negative (see e.g. Rose-Ackerman 1978 and Shleifer and Vishny 1993). ${ }^{28}$

\footnotetext{
${ }^{28}$ Rose-Ackerman (1978) for example warns of the difficulty of limiting corruption to areas in which it might be desirable. Shleifer and Vishny (1993) also argue that the fact that corruption has to be kept secret makes bureaucrats allocate resources to areas where there are opportunities for corruption
} 


\subsection{A benevolent CA}

As discussed in the introduction, earlier literature has typically focused on corruption at the lower level of government and has taken the highest level to be benevolent (Shleifer \& Vishny 1993 and Banerjee 1996). In order to enable comparison with this literature, we will in this section assume that the $\mathrm{CA}$ is benevolent. We assume that offices are not sold and that the CA maximizes the sum of consumer surplus and the revenues from fees less the monitoring cost. We also assume that the officials' profits are not included in the welfare function because they are corrupt. This problem poses an interesting trade-off. A low fee implies much consumer surplus. The cost of a low fee, however, is that the surplus from the fee is low and that the cost of monitoring officials is high.

In the monopoly case, the $\mathrm{CA}$ sets the fee to maximize welfare, $W$

$$
\max _{\theta} W=\left(1-\frac{c}{t}\right)\left(\frac{(a-p(\theta)) q(\theta)}{2}+\theta q(\theta)\right)+\frac{c}{t} \frac{\pi^{T}}{2}-\theta \frac{2 a-\theta}{4 b t} c .
$$

The optimal fee is equal to

$$
\theta^{*}=\frac{a}{2}\left(1-\frac{1+\frac{c}{t}}{3-5 \frac{c}{t}}\right),
$$

where $t>3 c$ is a necessary condition for a positive solution. In equilibrium, welfare is equal to $W^{*}=\frac{9 c^{2}-11 c t+4 t^{2}}{2 t(3 t-5 c)} \pi^{T}$. By comparing equation (16) and (30) we find that the optimal fee is higher for a benevolent CA than for a corrupt CA. The reason is the following: a corrupt $\mathrm{CA}$ has incentive to reduce the fee because it earns a residual on officials' profit. The benevolent CA has incentive to reduce the fee to increase consumer surplus but an additional incentive to increase the fee to reduce the cost of monitoring the official. Therefore, the price level is higher and petty corruption is lower if the CA's is benevolent.

Because the judiciary is assumed to be corrupt, an independent judiciary will in the case of theft bargain with the official, which leads to a low penalty. Therefore, the probability of theft is high and the CA selects a low fee. Hence, an independent and the social cost of this "can vastly exceed bribe revenues" (1993, p. 614). 
judiciary leads to much petty corruption and a low price compared to a dependent judiciary, also if the CA is benevolent.

In competition, there is as before no reason to use more than two officials. Social welfare consists of four terms: consumer surplus if not both officials steal plus consumer surplus if both steal plus incomes from fees if nobody steals less the cost of monitoring two officials. The maximization problem is therefore equal to

$$
\max _{\theta}\left(1-\left(\frac{c}{t}\right)^{2}\right) \frac{(a-\theta) q(\theta)}{2}+\left(\frac{c}{t}\right)^{2} 2 \frac{a^{2}}{4 b}+\left(1-\frac{c}{t}\right)^{2} \theta q(\theta)-2\left(1-\frac{c}{t}\right) \theta \frac{a-\theta}{b} c .
$$

The utility is unambiguously decreasing the higher the fee is, so the solution is simply $\theta^{*}=0 .{ }^{29}$ Note the difference from the monopoly case where officials would earn large profits when the fee is equal to zero. Interestingly, our theory resembles Shleifer and Vishny (1993) and Rose-Ackerman (1978) in that competition will be chosen by a benevolent authority, who minimizes corruption. ${ }^{30}$

\section{Discussion}

Using a new data set, which resembles the features of our model, we here consider a simple linear specification of the model in order to empirically study how the dependency of the judiciary is associated with corruption and the price level.

\subsection{Data}

To measure petty and grand corruption we use the "Transparency International Corruption Perception Index 2001", which includes both in the same variable. Corruption is computed as an average of different surveys assessing each countries performance ranging from 10 "highly corrupt" to 0 "perfectly clean" and is labelled CORR. ${ }^{31}$ Ob-

\footnotetext{
${ }^{29}$ If the officials' profits would also be included in the social welfare function, then the solution would, independent of market structure, be identical to the case of competition. The reason being that the CA's only objective is to reduce the dead weight loss.

${ }^{30}$ However, in competition, the judiciary becomes irrelevant as the fee is equal to zero and there is nothing to steal.

${ }^{31}$ The scale has been reversed from the index in which 0 indicated the highest level of corruption.
} 
servations from 79 countries are reported. The source for the price level is the World Business Environment Survey 1997 "Measuring Conditions for Business Operation and Growth" from the World Bank. The obtained country averages are from firm level data.

To capture the price level of governmental goods we use the question: "When firms in your industry do business with the government, how much of the contract value must they offer in additional or unofficial payments to secure the contract?". An index of 6 indicates a price above 20 percent of the value and 1 indicates a price equal to zero. The label for this variable is PRICE. There are 43 observations for PRICE.

In the model we define the judiciary as being dependent if the CA can decide the penalty for theft and make the monitoring decision. In order to capture this, we have compiled an index based on the US Department of State's evaluation of the degree to which the judicial system is subject to influence from the executive authority, as shown in the World Heritage Foundation's "Index of freedom" from 2001. We have constructed a scale where 1 implies "totally independent", 2 corresponds to "generally independent but occasionally influenced by the executive", 3 implies "the judiciary often shows signs of dependence of the executive" and 4 represents "the judiciary is subject to influence". The index is denoted by DEP and observations from 79 countries are reported.

We finally control for other potential determinants of corruption. According to La Porta et al. (1999) and Djankov et al. (2002), GNP per capita, the absolute value of the latitude of the country and the religions Protestantism, Catholicism and Islam may help explain corruption, bureaucratic delays and regulation. We therefore control for these variables $\left(\log\right.$ GNP, LAT, PROT, CATH and MUSLIM). ${ }^{32}$ La Porta et al. (1999) and Djankov et al. (2002) also argue that countries that have adopted civil law and socialistic law tend to have more dependent judiciaries and also more corruption than countries using common law. As we use a different proxy for the dependency of the judiciary we do not include legal origin in our regressions. ${ }^{33}$ Djankov et al. (2002)

\footnotetext{
${ }^{32} \log$ GNP denotes the logarithm of GNP per capita for the period 1970-1995. The source for the control variables is La Porta et al. (1999).

${ }^{33}$ Including legal origin as a control does not change our results qualitatively.
} 
use political rights as a potential explanatory variable of corruption in the form of regulation of entry of firms. We therefore control for political rights (POL) as well. ${ }^{34}$ The source for this variable is Freedom House (2000-2001). In Appendix Table B1, average values of the variables included in the regressions are shown.

The simple model specification for corruption is

$$
C O R R_{i}=\alpha+\beta D e p_{i}+\varphi_{j} X_{i j}+\epsilon_{i}
$$

and similarly for the price

$$
P R I C E_{i}=\alpha+\beta D e p_{i}+\varphi_{j} X_{i j}+\epsilon_{i}
$$

where $X_{i j}$ captures the control variables.

\subsection{Regression results}

The theoretical model gives different predictions of judicial dependency on corruption depending on the judiciary's ability to punish stealing officials (see Figure 6 for an illustration of these results). A dependent judiciary leads to more grand but less petty corruption. For low levels of the punishment (when a monopoly is selected) the overall effect is a reduction in corruption whereas for harsh punishments (when competition is selected) total corruption is enhanced. In the empirical estimations, a clear positive relationship between corruption and the dependency of the judiciary is found, as shown in Appendix Table B2, first controlling for logGNP, latitude, and then adding religion and finally political rights. According to the model, there may be two explanations for this. Either the capacity of dependent judiciaries to punish is relatively strong, or grand corruption is simply over reported in the perception index. ${ }^{35}$ In both cases, corruption and dependency of the judiciary are positively associated.

\footnotetext{
${ }^{34}$ Another standard control variable is civil rights. As it is highly correlated with political rights we do no report this variable. However, the results are robust to its inclusion.

${ }^{35}$ In fact, grand corruption may well be overreported since media usually reports this kind of corruption.
} 
Next, recall that the model predicts a dependent judiciary to generate high price levels both with a monopoly and with competition among officials. However, as a dependent judiciary may also lead to a shift to competition, the overall effect is ambiguous. The simple empirical specification allows for a first interpretation of the positive correlation between the dependency of the judiciary and the price level of government goods. In Appendix Table B3 the basic regression results are reported. By testing the relationship between PRICE and DEP we find that a dependent judiciary is associated with higher price levels than an independent judiciary and that the results are robust to the inclusion of standard regressors, such as the logarithm of GNP per capita, religion and political rights. According to the model, this would imply there is no structural shift in the degree of competition.

\subsection{Sensitivity analysis}

As a check for robustness, we also use another proxy for the dependency of the judiciaries, developed by Feld and Voigt (2003). In a worldwide survey, they have evaluated whether judiciaries "de facto" are dependent or not. De facto dependence is captured by an index consisting of the following five elements: (i) a short effective average term length of the members of the highest court, (ii) few judges in the highest court, (iii) small budgets for the courts, (iv) frequent changes of the legal rules, and (v) if the decisions of the highest court, in order to be implemented, depend on some action of other branches of the government. The number of observations is 46 and we label the variable DEP2.

As shown in Appendix Table B4, we obtain the same results with DEP2 as with DEP. A dependent judiciary is positively associated with corruption when controlling for $\log$ GDP, latitude, religion and political rights. Appendix Table B5 finally shows that also this measurement of a dependent judiciary is positively associated with the price level controlling for the same variables as in Appendix Table B3. However, it should be noted that there are only 28 observations included. 


\section{Summary and concluding remarks}

This paper addresses the issue of how the dependency of the judiciary affects corruption. It has been argued that when officials are corrupt, so are often the central authority and the judiciary. Understanding the interdependence of the central authority, lower level officials and the judiciary helps to explain how the institutional design of corrupt governments affects corruption. Owing to this interaction, low- and highlevel corruption, along with the price citizens have to pay for government goods, are typically affected differently by institutional design. Our results may be summarized as follows.

At the core of the distinction between an independent and a dependent judiciary lies the fact that independence gives rise to possibilities of bargaining when the judiciary is corrupt. We argue that the central authority can use a dependent judiciary to avoid bargaining between officials and the judiciary. By means of this control, theft by officials is reduced by increasing the judiciary's penalizing capacity. Consequently, the central authority can extract more rents (high-level corruption) at the expense of officials, which implies little low-level corruption.

The basic role of an independent judiciary, even if corrupt, is that it dissolves the exclusive power of the central authority, which reduces high-level corruption. On the other hand if the judiciary is too weak in the bargaining with officials, low-level corruption will be extensive. In other words, when power is divided among officials, the judiciary and the central authority, no agent will be able to create large rents, and thereby reducing total corruption. Examining a new data set of the dependency of the judiciary we achieve results supporting earlier empirical literature in that a more dependent judiciary is associated with more corruption. 


\section{References}

[1] Ades Alberto and Di Tella Rafael (1997). "The New Economics of Corruption: A Survey and some New Results.", Political Studies, 45, 496-515.

[2] Banerjee, Abhijit (1995). "Eliminating Corruption.", Mimeo, MIT, Massachusetts.

[3] Banerjee, Abhijit (1996). "Can Anything be Done about Corruption." in Current Issues in Economic Development: An Asian Perspective, Muhammad. G. Quibria and J. Malcolm Dowling (eds.) (Oxford University Press, Oxford).

[4] Bardhan, Pranab (1997). "Corruption and Development: A Review of Issues." Journal of Economic Literature, 35, 1320-1346.

[5] Baye, M. R., Kovenock, D, and De Vries, C. G. (1993). "Rigging the Lobbying Process: An Application of the All-Pay Auction." American Economic Review, 83, 289-301.

[6] Becker Gary S. and Stiegler Georg L. (1974). "Law Enforcement, Malfeasance, and Compensation of Enforcers." Journal of Legal Studies, 3, 1-19.

[7] Bernheim Douglas B. and Whinston Michael D. (1986), "Menu Auctions, Resource Allocation, and Economic Influence", Quarterly Journal of Economics, 101, 1-31.

[8] Boylan Richard T. (2000), "An Optimal Auction Perspective on Lobbying”, Social Choice and Welfare, 17, 55-68.

[9] Carmichael Lorne (1985). "Can Unemployment be Involuntary?" American Economic Review, 75, 1213-1214.

[10] Coolidge, Jacqueline G., and Rose-Ackerman, Susan (1997). "High-Level Rent Seeking and Corruption in African Regimes: Theory and Cases." World Bank Working Papers series: Governance, Corruption, Legal Reform, No: 1780. The World Bank, Washington DC. 
[11] Djankov Simeon, La Porta, Rafael, Lopez de Silanes, Florencio and Shleifer, Andrei (2002). "The Regulation of Entry." Quarterly Journal of Economics, 117, 1, $1-37$.

[12] Feld, Lars and Voigt, Stefan (2003). "Economic Growth and Judicial Independence: Cross Country Evidence Using a New Set of Indicators." European Journal of Political Economy, 19, 497-527.

[13] Glaeser Edward L. and Shleifer, Andrei (2002). "Legal Origins." Quarterly Journal of Economics, 117, 1193-1229.

[14] Goel, Rajeev K. and Rich, Daniel P. (1989). "On the Economic Incentives for Taking Bribes." Public Choice, 61, 269-275.

[15] Goel, Rajeev K and Nelson Michael A. (1998). "Corruption and Government Size: A Disaggregated Analysis." Public Choice, 97, 107-120.

[16] Gurgur, Tugrul and Shah, Anwar (2000). "Localization and Corruption: Panacea or Pandoras Box?" Mimeo, World Bank, Washington DC.

[17] The Heritage Foundation, "Index of Freedom 2001".

[18] Huther, Jeff and Shah, Anwar, Answar (2000). "Anti-corruption Policies and Programs: A Framework for evaluation." World Bank Policy Research Paper, No: 2501, December.

[19] Huntington, Samuel P. (1968). Political Order in Changing Societies. Yale University Press, New Haven, Connecticut.

[20] La Porta, Rafael, Lopez-de-Silanes Florencio, Shleifer, Andrei and Vishny, Robert (1999). "The Quality of Government." Journal of Law and Economics, 15, 222-279.

[21] La Porta, Rafael, Lopez-de-Silanes Florencio, Pop-Eleches Cristian and Andrei Shleifer (2004). "Judicial Checks and Balances." Journal of Political Economy, 112, 445-470 
[22] Leff, Nathaniel H. (1964). "Economic Development Through Bureaucratic Corruption." The American Behaviour Scientist, 8, 8-14.

[23] Klitgaard, Robert (1988). Controlling Corruption. University of California Press, London.

[24] Mookerjee, Dilip and Png, Ivan P. L. (1995). "Corruptible Supervisors and Law Enforcers: How Should They be Compensated?" Economic Journal, 105, 145-59.

[25] North, Douglas C. and Weingast, Barry R. (1989), "Constitutions and Commitment: Evolution of Institutions Governing Public Choice in 17th Century England," Journal of Economic History 49: 803-832.

[26] North, Douglass, C. (1981). Structure and Change in Economic History. W \&W Norton \& Company, Inc. New York, NY.

[27] Olson, Mancur (2000). Power and Prosperity, Outgrowing Communist and Capitalist Dictatorships, Basic Books, New York, NY.

[28] Polinsky, Mitchell A. and Shavell, Steven (2001). "Corruption and Optimal Law Enforcement." Journal of Public Economics, 81, 1-24.

[29] Riordan, William (1995). A Series of Very Plain Talks on Very Practical Politics. Signet Classic, New York, NY.

[30] Rose-Ackerman, Susan (1978). Corruption: A Study in Political Economy. Academic Press, New York, NY.

[31] Shleifer, Andrei and Vishny, Robert (1993). "Corruption.", Quarterly Journal of Economics, 108, 599-617.

[32] Stephenson Matthew (2001). "What is it, How Can It Be Measured, Why It Occurs?" Mimeo, The Worldbank, Washington DC.

[33] Swart, Koenraad, W. (1980). Sale of Office in the Seventeenth Century. Hes Publishers, Uthrect. 
[34] Transparency International Corruption Perception Index 2001.

[35] Tullock, Gordon (1980). "Efficient Rent Seeking." In Toward a Theory of the RentSeeking Society, Buchanan, James. M. Tollison, Robert D. and Tullock, Gordon (eds.) Texas University Press, Texas.

[36] Wade, Robert (1982). "The System of Administrative and Political Corruption: Canal Irrigation in South India." Journal of Development Studies, 18, 287-328.

[37] Wade, Robert (1984). "Irrigation Reform in Conditions of Populist Anarchy." Journal of Development Economics, 14, 285-328.

[38] World Business Environment Survey (1997). "Measuring Conditions for Business Operation and Growth." The World Bank, Washington DC. 


\section{A Appendix}

\section{A.1 Proof of Proposition (2)}

The penalty is equal to $t_{D}$ in a dependent system and $t_{I}=\phi t_{D}$ in an independent system where $\phi<1$. The expected price level is higher in the dependent case for two reasons. A higher penalty implies less theft, since $\mu=\frac{c}{t}$. This implies that the probability that the price is $\frac{a+\theta}{2}$ rather than $\frac{a}{2}$ is higher. Also, as shown below, a dependent judiciary generates a higher fee and hence a higher price level.

$$
\frac{\partial \theta}{\partial t}=\frac{a c \frac{n-1}{n}}{\left(\frac{n-1}{n}-2\left(1-\frac{c}{t}\right)\right)^{2} t^{2}}>0 .
$$

A dependent judiciary leads to less petty corruption compared to an independent judiciary since

$$
\frac{\partial P^{C}}{\partial t}=\frac{2\left(1-\frac{c}{t}\right) c \frac{n-1}{n}}{n\left(\frac{n-1}{n}-2\left(1-\frac{c}{t}\right)\right)^{3}} \pi^{T}<0 .
$$

Grand corruption on the ohter hand is larger because

$$
\frac{\partial G^{C}}{\partial t}=\frac{2\left(1-\frac{c}{t}\right) c\left(1-\frac{n-1}{n}-\frac{c}{t}\right)}{\left(\frac{n-1}{n}-2\left(1-\frac{c}{t}\right)\right)^{2} t^{2}} \pi^{T}>0 .
$$

The effect on overall corruption is

$$
\frac{\partial T^{C}}{\partial t}>(<) 0 \text { if } t>(<) \frac{4-3 \frac{n-1}{n}+\sqrt{\frac{n-1}{n}\left(8-7 \frac{n-1}{n}\right)}}{4\left(\frac{n-1}{n}-1\right)} c .
$$

The other root is not feasible in equilibrium.

\section{A.2 Proof of Proposition (4)}

The fee in the monopoly case is equal to

$$
\theta^{*}=\frac{a}{2}\left(1-\frac{\frac{n-1}{n}}{2\left(1-\frac{c}{t}\right)-\frac{n-1}{n}}\right)
$$


which is less than the fee in competition $\frac{a}{2}$ when $\theta^{*}>0$. The price in the monopoly case is equal to

$$
p^{M}=\frac{a}{2}\left(\frac{c}{t}+\left(1-\frac{c}{t}\right)\left(1-\frac{\frac{n-1}{n}-1+\frac{c}{t}}{2\left(1-\frac{c}{t}\right)-\frac{n-1}{n}}\right)\right),
$$

which is larger than the highest possible price in competition, $\frac{a}{2}$, when $\theta^{*}>0$. Finally, because the penalty is higher in case of a dependent judiciary compared to an independent judiciary, it follows that within competition the price level

$$
p^{C}=\frac{a}{2}\left(1-\left(\frac{c}{t}\right)^{2}\right)
$$

is higher in the dependent case.

\section{A.3 Proof of Proposition (5)}

By solving for $t$ in the inequality

$$
T_{M}^{C}=\frac{\left(1-\frac{c}{t}\right)^{2}\left(3-2 \frac{n-1}{n}-2 \frac{c}{t}\right)}{\left(\frac{n-1}{n}-2+2 \frac{c}{t}\right)^{2}} \pi^{T}<\left(1-\frac{c}{t}\right)^{2} \pi^{T}=T_{C}^{C}
$$

we can prove that there is more corruption in competition than in the monopoly case if $t>\frac{\sqrt{5-4 \frac{n-1}{n}}-2 \frac{n-1}{n}+3}{\left(1-\frac{n-1}{n}\right)^{2}} c$ (the other root is not feasible in equilibrium). Moreover, Bertrand competition eradicates the officials' expected profits and hence petty corruption. As for the last part of the proposition, a dependent judiciary leads to more overall corruption in competition than an independent judiciary does since

$$
\frac{\partial T^{C}}{\partial t}=\frac{2\left(1-\frac{c}{t}\right) c}{t^{2}} \pi^{T}>0
$$

\section{A.4 Proof of Proposition (6)}

The equilibrium welfare in competition is equal to

$$
W^{C}=\left(\left(1-\left(\frac{c}{t}\right)^{2}\right)\left(\frac{\left(a-\frac{a}{2}\right) \frac{\left(a-\frac{a}{2}\right)}{b}}{2}\right)+\left(1-\frac{c}{t}\right)^{2} \pi^{T}-2 \frac{\left(1-\frac{c}{t}\right) \pi^{T}}{t} c\right) .
$$


In the case of competition, welfare is larger when the judiciary is dependent compared to independent since

$$
\frac{\partial W^{C}}{\partial t}=\pi^{T} c \frac{4 t-5 c}{t^{3}}>0 .
$$

In the monopoly case, the effect of the independence of the judiciary on the cost of monitoring officials is ambiguous. 


\section{B Appendix}

Appendix Table B1 Summary Statistics

\begin{tabular}{|c|c|c|c|c|}
\hline \multicolumn{5}{|l|}{ Average values of: } \\
\hline CORR & $\begin{array}{c}\mathbf{5 . 2 6} \\
(2.48)\end{array}$ & & $\begin{array}{l}4.77 \\
(2.17)\end{array}$ & \\
\hline PRICE & & $\begin{array}{c}2.27 \\
(0.86)\end{array}$ & & $\begin{array}{c}2.11 \\
(0.76)\end{array}$ \\
\hline DEP & $\begin{array}{c}2.18 \\
(1.30)\end{array}$ & $\begin{array}{c}2.33 \\
(1.30)\end{array}$ & & \\
\hline DEP2 & & & $\begin{array}{c}\mathbf{0 . 4 2} \\
(0.24)\end{array}$ & $\begin{array}{c}\mathbf{0 . 4 6} \\
(0.23)\end{array}$ \\
\hline $\log G N P$ & $\begin{array}{c}7.62 \\
(1.34)\end{array}$ & $\begin{array}{c}7.61 \\
(1.08)\end{array}$ & $\begin{array}{c}7.99 \\
(1.25)\end{array}$ & $\begin{array}{c}7.94 \\
(0.95)\end{array}$ \\
\hline LAT & $\begin{array}{c}\mathbf{0 . 3 5} \\
(0.21)\end{array}$ & $\begin{array}{c}\mathbf{0 . 3 3} \\
(0.20)\end{array}$ & $\begin{array}{c}\mathbf{0 . 3 7} \\
(0.21)\end{array}$ & $\begin{array}{c}\mathbf{0 . 3 3} \\
(0.21)\end{array}$ \\
\hline PROT & $14.81 \%$ & $5.95 \%$ & $12.36 \%$ & $7.05 \%$ \\
\hline CATH & $38.18 \%$ & $51.62 \%$ & $44.88 \%$ & $59.12 \%$ \\
\hline MUSLIM & $14.51 \%$ & $14.54 \%$ & $11.47 \%$ & $10.80 \%$ \\
\hline OTHER & $32.50 \%$ & $27.89 \%$ & $31.29 \%$ & $23.03 \%$ \\
\hline POL & $\begin{array}{l}2.67 \\
(1.98)\end{array}$ & $\begin{array}{c}2.56 \\
(1.78)\end{array}$ & $\begin{array}{c}2.28 \\
(1.73)\end{array}$ & $\begin{array}{c}2.29 \\
(1.56)\end{array}$ \\
\hline \# Obs. & 79 & 43 & 46 & 28 \\
\hline
\end{tabular}

Note: Standard deviations are given in parentheses. 
Appendix Table B2 Results from OLS regression model on corruption using DEP

\begin{tabular}{|c|c|c|c|}
\hline \multicolumn{2}{|c|}{ Dependent variable: Corruption } & \multirow[b]{2}{*}{ [2] } & \multirow[b]{2}{*}{ [3] } \\
\hline & [1] & & \\
\hline \multirow[t]{2}{*}{ DEP } & $0.7129^{\mathrm{a}}$ & $0.5438^{\mathrm{a}}$ & $0.5682^{\mathrm{a}}$ \\
\hline & $(0.1914)$ & $(0.1238)$ & $(0.1468)$ \\
\hline \multirow[t]{2}{*}{$\log G N P$} & $-1.1011^{a}$ & $-1.1035^{a}$ & $-1.1185^{a}$ \\
\hline & $(0.2501)$ & $(0.2251)$ & $(0.2627)$ \\
\hline \multirow{2}{*}{ LAT } & 0.0398 & 0.9877 & 0.3160 \\
\hline & $(0.9616)$ & (1.0699) & (1.0705) \\
\hline \multicolumn{2}{|l|}{ PROT } & $-0.0354^{a}$ & $-0.0316^{a}$ \\
\hline & & $(0.0120)$ & $(0.0121)$ \\
\hline \multicolumn{2}{|l|}{ CATH } & 0.0031 & 0.0028 \\
\hline & & $(0.0049)$ & $(0.0046)$ \\
\hline \multicolumn{2}{|l|}{ MUSLIM } & 0.0012 & 0.0005 \\
\hline & & $(0.0054)$ & $(0.0065)$ \\
\hline \multirow{2}{*}{\multicolumn{2}{|c|}{ POL }} & & $(-0.0372)$ \\
\hline & & & $(0.1521)$ \\
\hline \multirow[t]{2}{*}{ CONS } & $12.0796^{\mathrm{a}}$ & $12.5016^{\mathrm{a}}$ & $12.6694^{\mathrm{a}}$ \\
\hline & $(2.2231)$ & (1.6008) & (2.0047) \\
\hline \multirow{2}{*}{$\begin{array}{c}\text { R-squared } \\
\text { \# Obs. }\end{array}$} & 0,6665 & 0,7552 & 0.7555 \\
\hline & 79 & 79 & 79 \\
\hline
\end{tabular}

Note: White-corrected standad errors below coefficients. a indicates significance at the 1 percent level, $\mathrm{b}$ at 5 percent and $\mathrm{c}$ at 10 percent. 
Appendix Table B3 Results from OLS regression model on the price level using DEP

\begin{tabular}{|c|c|c|c|}
\hline \multicolumn{4}{|c|}{ Dependent variable: Price } \\
\hline & [1] & [2] & [3] \\
\hline DEP & $\begin{array}{c}0.2193^{\mathrm{a}} \\
(0.0744)\end{array}$ & $\begin{array}{c}0.1573^{\mathrm{b}} \\
(0.0657)\end{array}$ & $\begin{array}{l}0.2044^{\mathrm{b}} \\
(0.0769)\end{array}$ \\
\hline $\log \mathrm{GNP}$ & $\begin{array}{l}-0.5116^{a} \\
(0.1070)\end{array}$ & $\begin{array}{l}-0.4866^{\mathrm{a}} \\
(0.1204)\end{array}$ & $\begin{array}{l}-0.4943^{\mathrm{a}} \\
(0.1106)\end{array}$ \\
\hline LAT & $\begin{array}{c}2.2029^{\mathrm{a}} \\
(0.3968)\end{array}$ & $\begin{array}{l}1.7343^{\mathrm{a}} \\
(0.4880)\end{array}$ & $\begin{array}{l}1.5725^{\mathrm{a}} \\
(0.4770)\end{array}$ \\
\hline PROT & & $\begin{array}{l}-0.0111 \\
(0.0094)\end{array}$ & $\begin{array}{l}-0.0120^{\mathrm{a}} \\
(0.0092)\end{array}$ \\
\hline CATH & & $\begin{array}{l}-0.0080^{a} \\
(0.0026)\end{array}$ & $\begin{array}{l}-0.0088^{a} \\
(0.0026)\end{array}$ \\
\hline MUSLIM & & $\begin{array}{l}-0.0047 \\
(0.0032)\end{array}$ & $\begin{array}{c}0.0014 \\
(0.0035)\end{array}$ \\
\hline POL & & & $\begin{array}{r}(-0.1095) \\
(0.0784)\end{array}$ \\
\hline CONS & $\begin{array}{l}4.9197^{\mathrm{a}} \\
(0.8931)\end{array}$ & $\begin{array}{c}5.5759^{\mathrm{a}} \\
(0.9504)\end{array}$ & $\begin{array}{l}5.8575^{\mathrm{a}} \\
(0.8877)\end{array}$ \\
\hline $\begin{array}{c}\text { R-squared } \\
\text { \# Obs. }\end{array}$ & $\begin{array}{c}0,5518 \\
43\end{array}$ & $\begin{array}{c}0,6325 \\
43\end{array}$ & $\begin{array}{c}0.6453 \\
43\end{array}$ \\
\hline
\end{tabular}

Note: White-corrected standad errors below coefficients. a indicates significance at the 1 percent level, $\mathrm{b}$ at 5 percent and $\mathrm{c}$ at 10 percent. 
Appendix Table B4 Results from OLS regression model on corruption using DEP2

\begin{tabular}{|c|c|c|c|}
\hline \multicolumn{2}{|c|}{ Dependent variable: Corruption } & \multirow[b]{2}{*}{ [2] } & \multirow[b]{2}{*}{ [3] } \\
\hline & [1] & & \\
\hline DEP2 & $\begin{array}{c}1.5662^{\mathrm{c}} \\
(0.8762)\end{array}$ & $\begin{array}{l}1.6197^{\mathrm{b}} \\
(0.7575)\end{array}$ & $\begin{array}{l}1.7573^{\mathrm{b}} \\
(0.6610)\end{array}$ \\
\hline $\log G N P$ & $\begin{array}{l}-1.2799^{a} \\
(0.1953)\end{array}$ & $\begin{array}{l}-1.2043^{a} \\
(0.1967)\end{array}$ & $\begin{array}{l}-1.2264^{a} \\
(02229)\end{array}$ \\
\hline LAT & $\begin{array}{c}0.1430 \\
(1.2959)\end{array}$ & $\begin{array}{c}1.1432 \\
(1.1697)\end{array}$ & $\begin{array}{c}0.9751 \\
(1.2258)\end{array}$ \\
\hline PROT & & $\begin{array}{l}-0.0237^{a} \\
(0.0085)\end{array}$ & $\begin{array}{l}-0.0238^{a} \\
(0.0085)\end{array}$ \\
\hline CATH & & $\begin{array}{c}0.0091 \\
(0.0060)\end{array}$ & $\begin{array}{c}0.0084 \\
(0.0057)\end{array}$ \\
\hline MUSLIM & & $\begin{array}{c}0.0010 \\
(0.0069)\end{array}$ & $\begin{array}{l}-0.0028 \\
(0.0084)\end{array}$ \\
\hline POL & & & $\begin{array}{l}-0.0715 \\
(0.1703)\end{array}$ \\
\hline CONS & $\begin{array}{l}14.3114^{\mathrm{a}} \\
(1.4861)\end{array}$ & $\begin{array}{l}13.1667^{\mathrm{a}} \\
(1.4441)\end{array}$ & $\begin{array}{l}13.5068^{\mathrm{a}} \\
(1.9253)\end{array}$ \\
\hline $\begin{array}{c}\text { R-squared } \\
\text { \# Obs. }\end{array}$ & $\begin{array}{c}0.6684 \\
46\end{array}$ & $\begin{array}{c}0.7534 \\
46\end{array}$ & $\begin{array}{c}0.7537 \\
46\end{array}$ \\
\hline
\end{tabular}

Note: White-corrected standad errors below coefficients. a indicates significance at the 1 percent level, $\mathrm{b}$ at 5 percent and $\mathrm{c}$ at 10 percent. 
Appendix Table B5 Results from OLS regression model on the price level using DEP2

\begin{tabular}{|c|c|c|c|}
\hline \multicolumn{4}{|c|}{ Dependent variable: Price } \\
\hline & [1] & [2] & [3] \\
\hline DEP2 & $\begin{array}{l}1.2355^{\mathrm{a}} \\
(0.3508)\end{array}$ & $\begin{array}{l}1.4129^{\mathrm{b}} \\
(0.5651)\end{array}$ & $\begin{array}{c}1.5182^{\mathrm{a}} \\
(0.5622)\end{array}$ \\
\hline $\log \mathrm{GNP}$ & $\begin{array}{l}-0.5286^{\mathrm{a}} \\
(0.0998)\end{array}$ & $\begin{array}{l}-0.4416^{\mathrm{a}} \\
(0.1417)\end{array}$ & $\begin{array}{c}0.4500^{a} \\
(0.1398)\end{array}$ \\
\hline LAT & $\begin{array}{l}2.2248^{a} \\
(0.4003)\end{array}$ & $\begin{array}{c}2.1859^{a} \\
(0.4265)\end{array}$ & $\begin{array}{l}1.8514^{a} \\
(0.5146)\end{array}$ \\
\hline PROT & & $\begin{array}{l}-0.0005 \\
(0.0107)\end{array}$ & $\begin{array}{l}-0.0019 \\
(0.0105)\end{array}$ \\
\hline CATH & & $\begin{array}{l}-0.0020 \\
(0.0043)\end{array}$ & $\begin{array}{c}0.0006 \\
(0.0048)\end{array}$ \\
\hline MUSLIM & & $\begin{array}{l}-0.0062 \\
(0.0066)\end{array}$ & $\begin{array}{c}0.0087 \\
(0.0069)\end{array}$ \\
\hline POL & & & $\begin{array}{l}-0.1091 \\
(0.0708)\end{array}$ \\
\hline CONS & $\begin{array}{l}5.0718^{\mathrm{a}} \\
(0.8192)\end{array}$ & $\begin{array}{l}4.0575^{\mathrm{a}} \\
(1.5532)\end{array}$ & $\begin{array}{l}4.5763^{a} \\
(1.5488)\end{array}$ \\
\hline R-squared & 0,5936 & 0.6126 & 0.6285 \\
\hline \# Obs. & 28 & 28 & 28 \\
\hline
\end{tabular}

Note: White-corrected standad errors below coefficients. a indicates significance at the 1 percent level, $\mathrm{b}$ at 5 percent and $\mathrm{c}$ at 10 percent. 


\section{CESifo Working Paper Series}

(for full list see www.cesifo-group.de)

1944 Panu Poutvaara and Mikael Priks, Unemployment and Gang Crime: Could Prosperity Backfire?, March 2007

1945 Burkhard Heer, On the Modeling of the Income Distribution Business Cycle Dynamics, March 2007

1946 Christoph A. Schaltegger and Lars P. Feld, Are Fiscal Adjustments less Successful in Decentralized Governments?, March 2007

1947 Giovanni Facchini, Marcelo Olarreaga, Peri Silva and Gerald Willmann, Substitutability and Protectionism: Latin America's Trade Policy and Imports from China and India, March 2007

1948 C. Mirjam van Praag and Bernard M. S. van Praag, The Benefits of Being Economics Professor A (and not Z), March 2007

1949 Astrid Hopfensitz and Frans van Winden, Dynamic Choice, Independence and Emotions, March 2007

1950 Guglielmo Maria Caporale and Luis A. Gil-Alana, A Multivariate Long-Memory Model with Structural Breaks, March 2007

1951 Mattias Ganslandt and Keith E. Maskus, Wholesale Price Discrimination and Parallel Imports, March 2007

1952 Michela Redoano, Fiscal Interactions Among European Countries. Does the EU Matter?, March 2007

1953 Stefan C. Wolter, Rémy Hübschi and Matthias Müller, Push or Pull? An Empirical Analysis of the Demand for Individual Project Grants from the Swiss National Science Foundation, March 2007

1954 Scott Alan Carson, African-American and White Inequality in the American South: Evidence from the $19^{\text {th }}$ Century Missouri State Prison, March 2007

1955 Peter Egger, Marko Koethenbuerger and Michael Smart, Do Fiscal Transfers Alleviate Business Tax Competition? Evidence from Germany, March 2007

1956 Panu Poutvaara and Lars-H. R. Siemers, Smoking and Social Interaction, March 2007

1957 Stephan Danninger and Fred Joutz, What Explains Germany's Rebounding Export Market Share?, March 2007

1958 Stefan Krasa and Mattias Polborn, Majority-efficiency and Competition-efficiency in a Binary Policy Model, March 2007 
1959 Thiess Buettner and Georg Wamser, Intercompany Loans and Profit Shifting Evidence from Company-Level Data, March 2007

1960 Per Pettersson-Lidbom and Mikael Priks, Behavior under Social Pressure: Empty Italian Stadiums and Referee Bias, April 2007

1961 Balázs Égert and Carol S. Leonard, Dutch Disease Scare in Kazakhstan: Is it real?, April 2007

1962 Paul De Grauwe and Pablo Rovira Kaltwasser, Modeling Optimism and Pessimism in the Foreign Exchange Market, April 2007

1963 Volker Grossmann and Thomas M. Steger, Anti-Competitive Conduct, In-House R\&D, and Growth, April 2007

1964 Steven Brakman and Charles van Marrewijk, It's a Big World After All, April 2007

1965 Mauro Ghinamo, Paolo M. Panteghini and Federico Revelli, FDI Determination and Corporate Tax Competition in a Volatile World, April 2007

1966 Inés Macho-Stadler and David Pérez-Castrillo, Optimal Monitoring to Implement Clean Technologies when Pollution is Random, April 2007

1967 Thomas Eichner and Ruediger Pethig, Efficient $\mathrm{CO}_{2}$ Emissions Control with National Emissions Taxes and International Emissions Trading, April 2007

1968 Michela Redoano, Does Centralization Affect the Number and Size of Lobbies?, April 2007

1969 Christian Gollier, Intergenerational Risk-Sharing and Risk-Taking of a Pension Fund, April 2007

1970 Swapan K. Bhattacharya and Biswa N. Bhattacharyay, Gains and Losses of India-China Trade Cooperation - a Gravity Model Impact Analysis, April 2007

1971 Gerhard Illing, Financial Stability and Monetary Policy - A Framework, April 2007

1972 Rainald Borck and Matthias Wrede, Commuting Subsidies with two Transport Modes, April 2007

1973 Frederick van der Ploeg, Prudent Budgetary Policy: Political Economy of Precautionary Taxation, April 2007

1974 Ben J. Heijdra and Ward E. Romp, Retirement, Pensions, and Ageing, April 2007

1975 Scott Alan Carson, Health during Industrialization: Evidence from the $19^{\text {th }}$ Century Pennsylvania State Prison System, April 2007

1976 Andreas Haufler and Ian Wooton, Competition for Firms in an Oligopolistic Industry: Do Firms or Countries Have to Pay?, April 2007 
1977 Eckhard Janeba, Exports, Unemployment and the Welfare State, April 2007

1978 Gernot Doppelhofer and Melvyn Weeks, Jointness of Growth Determinants, April 2007

1979 Edith Sand and Assaf Razin, The Role of Immigration in Sustaining the Social Security System: A Political Economy Approach, April 2007

1980 Marco Pagano and Giovanni Immordino, Optimal Regulation of Auditing, May 2007

1981 Ludger Woessmann, Fundamental Determinants of School Efficiency and Equity: German States as a Microcosm for OECD Countries, May 2007

1982 Bas Jacobs, Real Options and Human Capital Investment, May 2007

1983 Steinar Holden and Fredrik Wulfsberg, Are Real Wages Rigid Downwards?, May 2007

1984 Cheng Hsiao, M. Hashem Pesaran and Andreas Pick, Diagnostic Tests of Cross Section Independence for Nonlinear Panel Data Models, May 2007

1985 Luis Otávio Façanha and Marcelo Resende, Hierarchical Structure in Brazilian Industrial Firms: An Econometric Study, May 2007

1986 Ondřej Schneider, The EU Budget Dispute - A Blessing in Disguise?, May2007

1987 Sascha O. Becker and Ludger Woessmann, Was Weber Wrong? A Human Capital Theory of Protestant Economic History, May 2007

1988 Erkki Koskela and Rune Stenbacka, Equilibrium Unemployment with Outsourcing and Wage Solidarity under Labour Market Imperfections, May 2007

1989 Guglielmo Maria Caporale, Juncal Cunado and Luis A. Gil-Alana, Deterministic versus Stochastic Seasonal Fractional Integration and Structural Breaks, May 2007

1990 Cláudia Costa Storti and Paul De Grauwe, Globalization and the Price Decline of Illicit Drugs, May 2007

1991 Thomas Eichner and Ruediger Pethig, Pricing the Ecosystem and Taxing Ecosystem Services: A General Equilibrium Approach, May 2007

1992 Wladimir Raymond, Pierre Mohnen, Franz Palm and Sybrand Schim van der Loeff, The Behavior of the Maximum Likelihood Estimator of Dynamic Panel Data Sample Selection Models, May 2007

1993 Fahad Khalil, Jacques Lawarrée and Sungho Yun, Bribery vs. Extortion: Allowing the Lesser of two Evils, May 2007

1994 Thorvaldur Gylfason, The International Economics of Natural Resources and Growth, May 2007 
1995 Catherine Roux and Thomas von Ungern-Sternberg, Leniency Programs in a Multimarket Setting: Amnesty Plus and Penalty Plus, May 2007

1996 J. Atsu Amegashie, Bazoumana Ouattara and Eric Strobl, Moral Hazard and the Composition of Transfers: Theory with an Application to Foreign Aid, May 2007

1997 Wolfgang Buchholz and Wolfgang Peters, Equal Sacrifice and Fair Burden Sharing in a Public Goods Economy, May 2007

1998 Robert S. Chirinko and Debdulal Mallick, The Fisher/Cobb-Douglas Paradox, Factor Shares, and Cointegration, May 2007

1999 Petra M. Geraats, Political Pressures and Monetary Mystique, May 2007

2000 Hartmut Egger and Udo Kreickemeier, Firm Heterogeneity and the Labour Market Effects of Trade Liberalisation, May 2007

2001 Andreas Freytag and Friedrich Schneider, Monetary Commitment, Institutional Constraints and Inflation: Empirical Evidence for OECD Countries since the 1970s, May 2007

2002 Niclas Berggren, Henrik Jordahl and Panu Poutvaara, The Looks of a Winner: Beauty, Gender, and Electoral Success, May 2007

2003 Tomer Blumkin, Yoram Margalioth and Efraim Sadka, Incorporating Affirmative Action into the Welfare State, May 2007

2004 Harrie A. A. Verbon, Migrating Football Players, Transfer Fees and Migration Controls, May 2007

2005 Helmuth Cremer, Jean-Marie Lozachmeur and Pierre Pestieau, Income Taxation of Couples and the Tax Unit Choice, May 2007

2006 Michele Moretto and Paolo M. Panteghini, Preemption, Start-Up Decisions and the Firms' Capital Structure, May 2007

2007 Andreas Schäfer and Thomas M. Steger, Macroeconomic Consequences of Distributional Conflicts, May 2007

2008 Mikael Priks, Judiciaries in Corrupt Societies, June 2007 